\title{
Предраг Пипер
}

\section{ХРОНОТОП ТЕКСТА КАО ФУНКЦИОНАЛНО-СЕМАНТИЧКА КАТЕГОРИЈА СРПСКОХРВАТСКОГ ЈЕЗИКА \\ (Проблеми моделирана)}

1. Разматрање проблема моделирања хронотопа текста као функционално-семантичке категорије изгледа најупутније почети од неких терминолошких прецизирања како би се, пре свега, недвосмислено истакло шта није предмет овог рада. Наиме, термини хронотоп, текст, интертекстуалне релације, унутартекстуалне релације и још неки који ће се даље употребљавати припадају и појмовном систему модерне поетике. Као што је у наслову истакнуто, предмет наше пажње је превасходно лингвистичке природе. Повремене паралеле између хронотопа текста као предмета лингвистике и хронотопа уметничког текста као предмета структуралне поетике биће углавном у функцији истицања посебности хронотопа текста као предмета лингвистичког истраживања.

Друго, доста је уобичајено да се садржај појма текст у лингвистичким радовима ближе не одређује, као ни неки други темељни појмови науке о језику (реч, синтагма, реченица...), него се то обично препушта углавном успешном подразумевању. Пошто овде нема могућности, а ни потребе да се више места да проблему дефинисања текста, док са друге стране изгледа пожељно да се на самом почетку укаже на она обележја текста који су за овај предмет релевантна, ограничићу се општом констатацијом да се даље текстом називају реченичне или надреченичне синтаксичке, семантичке и комуникативне целине које могу да функционишу као самостални искази. Структура текста се, дакле, види као синтаксичка структура која је, са једне стране ограничена реченичном структуром, док се њена друга граница теже одређује - то је једно од отворених питања лингвистике текста, односно анализе дискурса. Неки типови текстова, као што се зна, имају доста устаљене граничне маркере почетка, краја или обележја медијалне структуре текста (нпр. говори, писма, бајке, молитве, телефонски разговори, радио и телеграфске пору- 
ке и сл.), док су у многим другим типовима текстова таква обележја често знатно слабије изражена (научни реферати, реплике и др.). Међутим, без обзира на степен структурне сложености, и формалне изражености унутрашње структуре и граничних елемената, обавезно својство текста је да функционише или да може да функционише као целовити исказ.

2. Полазна теза у овом разматрању јесте да је текст, као посебан и конститутивни елеменат говорне ситуације, и у језичком систему представљен посебним комплексом функционално-семантичких категорија. Даље ћу се у вези с тим служити појмовима који припадају теорији која се у једном делу славистике, посебно у русистици, данас најчешће назива теоријом функционалне граматике, иако су у мање или више друкчијем појмовно-терминолошком руху идеје такве верзије савремене функционалне граматике претресане и у оквиру других старијих и новијих теоријских модела и лингвистичких праваца. ${ }^{1}$

За предмет овог реферата најбитнија је чињеница да се у оквиру теорије функционалне граматике као један од централних појмова издваја функционално-семантичка категорија као систем функционално-семантичких садржаја са извесним заједничким категоријалним обележјем (време, лице, количина и др.), чији је израз обично јаче или слабије граматикализован у језгру функционално-семантичке категорије и лексикализован на њеној периферији. ${ }^{2}$

У досадашњим испитивањима, у инвентарисању и покушајима систематизовања функционално-семантичких категорија није се узимала у обзир иначе добро позната чињеница да језички универзум није само одраз ванјезичког универзума него и себе самог, тј. чињеница да се језиком реферише и о језику, што не може бити ирелевантно за систем функционално-семантичких категорија. Та чињеница да је сваки језик глобална и истовремено уникално специфична слика универзума, како ванјезичког тако и језичког, није чисто теоријски конструкт него се за-

${ }^{1}$ Теория функииональной грамматики. Введение. Аспектуальность. Временная локализованность. Таксис. Отв. ред. а. В. Бондарко. - Ленинград: Наука, 1988. О том моделу функционалне граматике в. у раду Д. Војводића у овом зборнику.

${ }^{2}$ Овде се изоставља могућна критичка анализа термина функционално-семантичка категорија и његовог појмовног садржаја, као и његовог односа према појмовима семантичка категорија и функиионално-семантичко поле, како би се више пажње могло посветити основном предмету рада. Погледи аутора на та питања делом су садржани у напомени 3 , посебно у монографији о заменичким прилозима (1983), и у рецензији објављеној у 3борнику Матище српске за славистику, 1986, св. 31, стр. 177-180. 
снива на конкретним језичким чињеницама: у различитим језицима постоје специфична језичка средства којима се реферише о језику, не само лексички и на парадигматском плану, него и таква која су уграђена у граматичку структуру сваког исказа, квалификујући поједине његове делове или целину (са становишта реалности / иреалности, познатог и новог, одређеног и неодређеног итд.). Чињеница да се и ту ради о извесном општем категоријалном садржају (текст) који има и у језичком систему доста разуђен израз, те да је текст као основна функционално-семантичка категорија конститутивни елемент говорне ситуације, пружа довољно основа да се у оквиру моделирања структуре и начина функционисања појединих категорија у различитим језицима - посебно испитује и структура текста.

Основна специфичност текста у односу на поједине функционално-семантичке категорије јесте у томе што текст има обавезно просторни, временски, количински, персонални итд. категоријални аспект одражен у специфичном комплексу функционално-семантичких категорија, које са мање-више друкчијим садржајем постоје и изван текста, а које се у тексту остварују на посебан начин и са знатно већим степеном синкретичности и функционалне комплементарности (в. даље) него када су у питању одговарајући вантекстуални денотати.

Према томе, с једне стране, текст као сложени језички знак реферише истовремено о више категоријалних ситуација (дијатезна, персонална, просторна, временска и др.), док је, са друге стране, текст истовремено и сопствени денотат, о чему реферише посебним метатекстуалним средствима, ${ }^{3}$ нпр.: наводно, то јест, другим речима, тачније речено, на пример и сл. У комплексу тих метатекстуалних средстава врло јасно се издвајају она која реферишу о просторним и временским или о просторно-временским димензијама текста, као израз сложене функционално-семантичке категорије текста коју је најпримереније означити хронотопом текста (или, прецизније, метатекстуалним хронотопом). Хронотоп текста као функционално-семантичка категорија (даље само: хронотоп текста) остварује се независно од тога да ли је у одређеном тексту поетска функција доминантна или није, како преко анафоре, конексије, глутинације и уопште граматичких средстава кохезије текста, тако и помоћу низа специјалних метатекстуалних лексема и конструкција,

${ }^{3}$ B. о томе: A. Wierzbicka, Metatekst w tekście. - [In:] O spójności tekstu. - Red. M. R. Mayenowa. Wroclaw - Warszawa - Kraków - Gdańsk 1971, s. 105-121. Један облик испољавања метатекстуалности у српскохрватском језику разматрам у раду: O rednim prilozima u srpskohrvatskom jeziku. - Folia linguistica polono-jugoslavica, I, Katowice, 1988, c. 23-41. 
као што су, на пример, пре свега, најзад, на крају, и последне, претходно, далье, напред, и један и други, прво... друго... треће.. и сл. Ни поетски текст очигледно не искључује метатекстуални хронотоп.

3. Моделирање формално-структурне, семантичке и комуникативне стране текста на српскохрватском или неком другом језику обухватало би у том смислу и моделирање хронотопа текста.

Пошто се за термин модел везује велики број садржаја које у њему лингвисти различитих школа и праваца очитавају, неће бити сувишно да истакнем да делим мишљење оних лингвиста према којима модели постоје у лингвистици, а структуре, обрасци и њихови функционално-семантички садржаји у језику, што се према неким другим мишљењима такође може називати моделом за разлику од лингвистичког. Прикључујући се првом, ужем схватању модела њиме, дакле, називам артифицијелне, научне, лингвистичке објекте који се стварају са циљем да покажу пре свега релевантне аспекте одређених језичких објеката (формалних, семантичких и/или функционалних).

Иако модел хронотопа текста до сада, колико ми је познато, није био посебан предмет истраживања ни у српскохрватском ни у неком другом језику, на утврђивању појединих његових својстава, посебно оних која су релевантна за граматику реченице и граматику дискурса индиректно је доста урађено, пре свега кроз испитивање средстава којима се остварује кохезија текста, иако је хронотопска функција само део њиховог функционалног потенцијала. С обзиром на сложеност овако схваћеног предмета, излагање је усмерено на покушај да се размотре неке важније тачке и односи у могућном лингвистичком моделу хронотопа текста као функционално-семантичке категорије у српскохрватском језику. При томе се неће разматрати они облици хронотопа текста који су у оквиру проучавања анафоре, конексије и сличних појава већ мање-више познати (мада не са становишта моделирања хронотопа) него ће се даље у фокус стављати оне појаве које су слабије изражене граматикализованости до сада углавном остављане по страни. Ипак, и за тако усмерено разматрање неопходно је пре свега дати глобалну скицу односа у систему хронотопа текста.

4. За моделирање хронотопа текста најреалнија је чињеница да је хронотоп у основи локализација - просторно-временска, односно просторна или временска, због чега је основано претпоставити да механизам хронотопа функционише у бити на сличан начин на који и изван категоријалног комплекса текста функционишу категорије времена, простора, компарације, посесивности и друге које се заснивају на категоријалној ситуацији локализације, која укључује као конститутивне 
факторе - просторни, временски или неки други локализатор, објекат локализације и оријентир (односно конкретизатор релације између локализатора и објекта локализације), а као променљиве категоријалне величине укључује локативност или директивност (аблативну, адлативну или перлативну), - обележја којима је дата локализација одређена с обзиром на могућност динамичког односа међу елементима категоријалне ситуације.

Локализација текста, локализација текстом или локализација у границама текста може се остваривати или (I) преко његових формалних просторно-временских својстава, или (II) кроз структуру његовог садржаја.

5. Прва могућност је можда мање интересантна, али заслужује краћи осврт. Полазећи од различитих просторно-временских локација у зависности од тога да ли је реч о локализацији у границама истог објекта или о локализацији у којој учествују сасвим посебни облици - текст може бити посматран са та два становишта.

У првом случају (унутрашња локализација) то може бити или интратекстуална локализација, тј. локализација елемента текста у односу на неки други његов елемент, сегмент или блок, као, на пример, у помињаним случајевима заменичке анафоре. Рецимо, у То је све заменица упућује на претходни део текста, или у целини или у његовом закључном сегменту, док је у катафорском упућивању као, на пример, у реченици Чујте и ово објекат локализације део текста који следи. Поред критерија према опозицији „испред” / „иза”, односно „пре” / „после”, могу бити релевантни и неки други, нпр. „проксималност” / „дисталност”, упор.: И y овом и у оном случају узрок је био исти, или И у првом и у другом случају узрок је био исти, где прва заменица, одн. редни број упућује на ближи, а друга на даљи антецедент и сл.

За разлику од такве просторно-временске, антериорно/постериорне интратекстуалне локализације могућна је, иако није граматикализована, и таква у којој учествују под-текстуалне целине истог текста чији хронотоп може бити у тексту експлициран лексемама као што су: предговор, поговор, пролог, епилог, поднаслов, наднаслов, међунаслов, антрфиле, уводник, потпис, анекс, прилог, индекс, фуснота, наводи итд., дакле у целинама које у свом општем називу садрже локализацију у односу на основни део текста.

6. Сличан је спољашњи хронотоп текста кроз који се текст као целина одређује

(a) према другим текстовима, о чему реферишу такви називи текстова као увод, превод, извод, препис, натпис..., при чему се интертекстуалне релације ту не исцрпљују само у хронотопу; 
(б) према ситуацији у којој функционишу, нпр.: упутница, доставница, исписница, епитаф, натпис...

Као и у претходном случају, код интратекстуалне локализације суб-текстова према основном делу текста, и интертекстуално-ситуативна локализација може бити експлицитна, тј. номинално присутна у тексту или имплицитна, када је на основу структуре текста утврђују учесници у комуникацији.

Поред тога, неке јединице хронотопа могу имати и више од једне функције, упор.: увод у интратекстуалној функцији (обично 'део књиге') и у интертекстуалној функцији (нпр. Увод у лингвистику као наслов уџбеника у односу на, рецимо, Опиту лингвистику).

За проучавање семантичких транспозиција, вишезначности и језичких метафора свакако су интересантнија она језичка средства помоћу којих се садржај текста осмишљава као известан апстрактан простор у којем се налазе као локализатори или објекти локализације поједини сегменти семантичког или комуникативног садржаја текста. Не само што се поједини делови садржаја текста могу описивати као објекти који се у тексту прескачу, испуштају, изостављају, одбаиују, преносе, подвлаче, провлаче кроз текст, виде између редова, дотичу, обилазе, протурају, извлаче итд., дакле просторно осмишљавају, него се и за истицање комуникативног суодноса и хијерархије компонената смисаоне структуре текста употребљавају посебни просторносно уобличени изрази, нпр.: с једне стране, с друге стране, насупрот томе, паралелно с тим, изван тога, по страни, на маргини, у иентру пажне, у средишту пажне, на том пољу, на том нивоу, разини, у том оквиру, домену, кругу, у тој области, равни, у првом плану, у другом плану, на тој / таквој позадини, далеко од тога, блиско томе и сл.

Ови и други слични изрази унутрашњег хронотопа текста припадају једном семантичком подсистему који се релативно лако може моделирати на начин сличан оном на који су у многим језицима описани, нпр. предлошки, префиксални, прилошки и други подсистеми. Оно што их од других сличних подсистема у истом језику издваја нису само структурне специфичности него и категоријални денотат: а то је садржај текста који се овим средствима просторносно обликује и комуникативно профилира.

7. Модел хронотопа текста као функционално-семантичке категорије савременог српскохрватског језика, чије су важније особине предмет пажње у овом реферату, у теоријско-методолошком и појмовно-терминолошком погледу знатним делом наслања се на сличне лингвистичке 
моделе неких других језичких структура (нпр., заменичких, префиксалних, предлошких, прилошких...) јаче или слабије одређених једном специјалном лингвистичком теоријом која се, не сасвим прецизно, према једној од својих ранијих верзија, обично назива локалистичка теорија падежа, било да је реч о њеној формално-граматичкој, таксонимијској, било структуралној или генеративној верзији. ${ }^{4}$

За наш предмет посебно је интересантна на почетку поменута чињеница да постоји доста додирних тачака између лингвистичких модела у оквиру локалистичке теорије падежа и теорије хронотопа поетског текста у структуралној поетици. Те тачке још нису биле предмет посебних испитивања. Једна од главних разлика између те две специјалне теорије одређена је природом самог предмета моделирања; категорија времена и простора у језичком систему и у његовим говорним реализацијама у многим језицима, ако не и свим (као изузетак обично се наводи језик племена Хопи) оштрије су издиференциране него што је то случај са простором и временом поетског текста. Простор и време у моделу лингвистичког хронотопа текста у том погледу су (дакле с обзиром на степен структурне и функционалне повезаности) ближи хронотопу поетског текста, уз разуме се, бројне веће или мање разлике које би тек требало да буду подробно проучене у евентуалним будућим истраживањима. Пошто та локалистичка теорија падежа као теорија моделирања просторносно осмишљених непросторних сфера добија у новије време индиректан ослонац у когнитивној психологији, где се у основу модела процеса сазнавања универзума често стављају критерији локализације и оријентације, унутрашњег и спољашњег и други, исцрпно испитивање

${ }^{4}$ Ову проблематику сам, углавном на српскохрватском и руском материјалу, разматрао поред других у радовима: Обележавање просторних односа предлошким и падежним конструкцијама у савременом руском и савременом српскохрватском књижевном језику. - Прилози проучавағу језика, 1977-1978, 13-14, стр. 1-50; O psiholingvističkim osnovama opozicije „unutra/spolja” kao mogućnom konstitutivnom faktoru sistema semantičkih kategorija. - Godišnjak Saveza društava za primenjenu lingvistiku Srbije, 1984, 7-8, str. 223-231; Zamenički prilozi (gramatički status i semantički tipovi). Novi Sad, 1983, посебно стр. 84-95; Локалистская теория падежей и функциональная грамматика руского языка как иностранного. - Русский язык за рубежом, Москва, 1986, 6, стр. 79-83; Language in space and space in language. - [In:] Yugoslav General Linguistics. Selected, edited, and introduced by Milorad Radovanović. - Amsterdam: John Benjamins, 1988, p. 241-263, Локализација као принцип структурирања граматичких и семантичких категорија. (У штампи у зборнику реферата са конференције Комисије за проучавање граматичке структуре словенских језика одржане 1989. год. у Малој Моравки). 
могућности апликација дате лингвистичке теорије на моделирање хронотопа текста могло би и у емпиријском и у теоријском погледу боље осветлити однос између когнитивне психологије и теорије дискурса, а у даљој перспективи, вероватно, и њихов однос према моделима хронотопа поетских текстова.

8. У закључку овог рефератски уобличеног дискурса о хронотопу текста могло би се, дакле, рећи да је хронотоп текста као функционално-семантичке категорије систем граматичких и лексичких средстава којима се поједини елементи текста у формално-структурно и/или у семантичко-функционалном погледу просторно-временски локализују у односу на друге делове истог текста, или којима се читав текст локализује у односу на друге текстове или говорну ситуацију.

Моделирање хронотопа текста као функционално-семантичке категорије одређено је, пре свега, чињеницом да постоји више слојева таквог хронотопа: I спољашњи (а - интертекстуални, 6 - текстуално-ситуативни), и II унутрашњи (интратекстуални; а - формално-структурни, 6 - функционално-семантички), и природно се наслања на теоријска искуства лингвистичког моделирања вантекстуалних просторних и временских локализација, при чему се полази од структуре категоријалне ситуације локализације и неких општих критерија као што су интралокализација / екстралокализација, вертикална и хоризонтална локализација, антериорност и постериорност, проксималност и дисталност, локативност и директивност и др., које су у целини организоване у систем субординарних опозиција. Утврђивање конкретних одлика тог система припада евентуалним будућим истраживањима.

Граматичко језгро хронотопа текста чине анафора, конексија, глутинација и уопште средства којима се остварује кохезија текста, иако се функционални потенцијал тих средстава ни у ком случају не исцрпљује у хронотопу. Пажња је у реферату била више усмерена на слабије граматикализоване облике хронотопа текста, посебно на оне који функционишу као просторне метафоре, иако просторносна уобличеност средстава хронотопа текста свакако није обавезна, што показују, рецимо, хронотопски маркери граница дискурса бајке, писма, телефонског разговора итд., или хронотопски маркери граница дискурса научног реферата који у српскохрватском језику обично звуче као „Поштоване колеге”, с једне стране, а са друге - „Хвала на пажњи”. 
Предраг Пипер

О ФУНКЦИОНАЛЬНО-СЕМАНТИЧЕСКОЙ КАТЕГОРИИ ХРОНОТОПА ТЕКСТА

В СЕРБСКОХОРВАТСКОМ ЯЗЫКЕ

(проблемы моделирования)

Резюме

В настоящей статье рассматривается вопрос о статусе текста как комплекса функционально-семантических категорий (в рамках теоретической модели функциональной грамматики, которая разработывается в современной русистике и славистике), а также вопрос о возможности выделения хронотопа текста как отдельной сложной функционально-семантической категории в комплексе функционально-семантических категорий текста.

В статье специальное внимание уделяется типологии видов пространственной и временной локализации в структуре текста, или по отношению к тексту (в частности - 1. внешнему хронотопу: (а) интертекстуальному, (б) текстуально-ситуативному; 2. внутреннему (интратекстуальному) хронотопу: (а) формально-структурному, (6) функционально-семантическому), а также менее грамматикализованным средствам выражения хронотопа текста в сербскохорватском языке. 